\section{Management and treatment of obstetric bacteraemic shock}

\section{DF HAWKINS Institute of Obstetrics and Gynaecology, Hammersmith Hospital, London W12 OHS, UK}

Bacteraemic shock may occur as a complication of septic abortion. Since the Abortion Act of 1967, this situation has become rare in Great Britain. presumably due to a great reduction in illegal abortions conducted in circumstances and by methods conducive to sepsis. Occasionally, septic shock is seen during pregnancy in relation to an infected Shirodkar suture, an exacerbation of pre-existing pelvic inflammatory disease, or peritonitis caused by, for example, a ruptured appendix. Other cases occur with intrauterine infections related to premature rupture of the membranes, particularly if the subsequent delivery is operative. In the puerperium, Gram-negative infections are usually treated promptly, but bacteraemic shock can complicate pelvic infection related to retained products of conception or, rarely, a degenerating uterine fibromyoma.

\section{Early diagnosis}

This is the key to effective management and depends on clinical recognition of the condition. A severe Gram-negative infection should be suspected at once in patients with a predisposing history who are ill out of proportion to the local signs of infection and out of proportion to the systemic indications of infection such as pyrexia. Hypothermia and hypotension, with reduced urinary output, elevation of the blood urea, and haematological evidence of disseminated intravascular coagulation may be seen before bacteriological confirmation of the diagnosis is obtained.

\section{Initial management}

This should consist of intravenous fluids and antibiotics and, if there is oliguria, diuretics. The fluids must be controlled by a central venous pressure (CVP) line, continuing the infusion until the CVP starts to rise, and with 4 to 6 hourly plasma electrolyte estimations. If hypotension persists then it may be necessary to use chlorpromazine, isoprenaline, or steroids to expand the intravascular compartment and permit further fluid infusion to give adequate tissue perfusion. If there is any anaemia or haemorrhage, whole blood should be the initial choice of fluid, not the afterthought. The antibiotic regimen may include an agent such as flucloxacillin or a cephalosporin, an aminoglycoside such as gentamicin, and metronidazole to cope with anaerobes. If there is evidence of clostridial infection the regimen should incorporate benzylpenicillin; if anaerobes are found in blood cultures and the patient remains seriously ill, lincomycin may be preferred to gentamicin and metronidazole. If the patient is responding well, it is a mistake to change antibiotics on the basis of laboratory sensitivities. With oliguria, intravenous frusemide, an initial dose of 25 or $50 \mathrm{mg}$, and if there is no response a dose of $250 \mathrm{mg}$, does no harm and may achieve diuresis. The risk of exacerbating the potential nephrotoxicity of cephalosporins or aminoglycosides is small with short-term use of frusemide in this way.

\section{Subsequent management}

If the patient's condition fails to respond promptly, management in an intensive care situation is essential. Obstetric patients are usually basically healthy women, and however ill they are, management orientated to the maintenance of systems is usually effective in the long run. Respiratory maintenance, using the ventilator, may be required. Peritoneal dialysis is particularly appropriate if there is renal failure, as it gives good control of fluid balance and electrolytes with a minimum of cardiovascular disturbance and at the same time provides peritoneal lavage if there is peritonitis. Gastric aspiration may be needed if ileus or obstruction supervenes. Nutrition should be started early to cope with a hypercatabolic state, using the oral route if possible, otherwise intravenous aminoacids, plasma, and whole blood if appropriate. Some authorities like lipid infusions to maintain calory intake but there is a small risk of untoward reaction or excessive lipaemia. Physiotherapy to legs and chest is essential.

\section{Surgery}

The role of surgery is minimal. When there is peritonitis laparotomy will doubtless continue to be performed for diagnostic reasons, to repair bowel perforation or to evacuate pus. In fact, exploration can often be postponed, sometimes for weeks, until bactaemic shock and infection are controlled, when the operation may well no longer be necessary. It is now well established that, in very seriously ill women, surgical assaults designed to remove an infected uterus or even septic products of conception from its cavity do more harm than good. ${ }^{1}$

Remaining aspects of management which should be considered are renal diagnostic procedures, steroids, and heparin. If there is renal failure, renal 
biopsy adds nothing to management and may have disastrous consequences; high-dose nephrograms do not affect treatment and may render an oliguric patient anuric. Steroid regimens have been used in the treatment of bacteraemic shock in the USA, but they can have major complications and are employed only as a last resort in the moribund patient in Great Britain. Heparin infusions should only be used to treat disseminated intravascular coagulation in these patients in the complete absence of bleeding and, in my opinion, if circulating fragmented red cells confirm the coagulopathy.
Reference

${ }^{1}$ Hawkins DF, Sevitt LH, Fairbrother PF, Tothill AU. Management of septic abortion with renal failure. $N$ Engl $J$ Med 1975;292:722-5.

Requests for reprints to: Professor DF Hawkins, Institute of Obstetrics and Gynaecology, Hammersmith Hospital, Du Cane Road, London W12 0HS, UK.

\section{Reports and Bulletins prepared by the Association of Clinical Biochemists}

The following reports and bulletins are published by the Association of Clinical Biochemists. They may be obtained from The Publishing Department, British Medical Journal (ACB Technical Bulletins), BMA House, Tavistock Square, London WC1H 9JR. Overseas readers should remit by British Postal or Money Order.

SCIENTIFIC REVIEWS (price $£ 1 \cdot 00 / \$ 2.00$ each)

1 The assessment of thyroid function March 1971 FV FLYNN and JR HOBBS

2 Renal function tests suitable for clinical practice January 1972 FL MITCHELL, N VEALL, and RWE WATTS

3 Biochemical tests for the assessment of fetoplacental function May 1975 CE WILDE and RE OAKEY

4 Test of exocrine pancreatic function March 1977 AH GOWENLOCK

5 Assay of cholinesterase in clinical chemistry March 1979 ELSIE SILK, J KING, and MARY WHITTAKER

TECHNICAL BULLETINS (price $£ 1 \cdot 00 / \$ 2.00$ each)

22 Bilirubin standards and the determination of bilirubin by manual and technicon AutoAnalyzer methods January 1971 BARBARA BILLING, RUTH HASLAM, and N WALD

23 Interchangeable cells for spectrophotometers and fluorimeters September 1971 ss BROWN and AH GOWENLOCK

24 Simple tests to detect poisons March 1972 BW MEADE et al.

25 Blood gas analysers May 1972 K DIXON

26 Kits for enzyme activity determination September 1972 SB ROSALKI and D TARLOW

27 Assessment of pumps suitable for incorporation into existing continuous flow analytical systems November 1972 A FLECK et al.

28 Routine clinical measurements of transferrin in human serum September 1973 K DIXON
29 Control materials for clinical biochemistry (5th edition) September 1973 JF STEVENS

30 Notes on the quality of performance of serum cholesterol assays September 1973 ss BROWN

31 Determination of uric acid in blood and in urine July 1974 RWE WATTS

32 A survey of amino acid analysers readily available in the United Kingdom September 1974 JE CARLYLE and P PURKISS

33 Definitions of some words and terms used in automated analysis November 1974 A FLECK, R ROBINSON, SS BROWN, and JR HOBBS

34 Measurement of albumin in the sera of patients January 1975 LINDA SLATER, PM CARTER, and JR HOBBS

35 Investigation of the validity of temperature correction factors for serum aspartate and alanine transaminases March 1975 SB ROSALKI et al.

36 Factors influencing the assay of creatinine November 1975 JGH COOK

37 A survey of enzyme reaction rate analysers readily available in the United Kingdom July 1977 RA SAUNDERS and RF BURNS

38 Transport of specimens for clinical chemistry analysis November 1977 P WILDING, JF ZILVA, and CE WILDE

39 A scheme for the evaluation of diagnostic kits May 1978 PH LLOYD

40 A practical guide to gamma-counting in radioimmunoassay January 1980 CE WILDE and D OTTEWELL 